\title{
APPENDIX. \\ MICROPALEONTOLOGICAL AND SEDIMENTOLOGICAL ASPECTS OF HIGH ATLAS CRETACEOUS ONSHORE SEDIMENTS (ATLAS-GULF, MOROCCO) ${ }^{1}$
}

\author{
Arif Butt, Universität Tübingen \\ and \\ Johannes Stets and Paul Wurster, Geologisches Institut der Universität Bonn ${ }^{2}$
}

\begin{abstract}
Micropaleontological and sedimentological data of the Lower to mid-Cretaceous sequence in the Western High Atlas of Morocco support the existence of a deltoid/triangular Atlas-Gulf. Transgressions and regressions in the Gulf area documented by the micropaleontological record include significant transgressive events during the Berriasian to Valanginian, early Barremian, late Aptian, and Turonian, and regressions in the late Hauterivian and late Barremian to early Aptian. Frequent sea-level oscillations are recorded in the Cenomanian. Continental, lagoonal, littoral, and inner to mid-shelf conditions are deduced from micropaleontological and sedimentological data. Intertonging of marine and nonmarine paleoenvironmental conditions exhibits transitional characteristics between the Atlantic province and the inner part of the Gulf. Assuming a steady subsidence of the Gulf area because of its location in the mobile High Atlas belt, eustatic changes in sea level may be the most important factor controlling sedimentation, paleoenvironment, and paleobathymetry in the Atlas-Gulf.
\end{abstract}

\section{INTRODUCTION}

Since 1975, a working group of the Geologisches Institut der Universität Bonn has conducted geological field work on the Cretaceous of the High Atlas area of Morocco to reconstruct the Cretaceous geography of the region (Behrens et al., 1978, Behrens and Siehl, 1982, Wurster and Stets, 1982, Stamm and Thein, 1982). This work is equivalent to the offshore activities of the Deep Sea Drilling Project. The onshore activities of the Bonn working group were initiated by Dr. Hans Closs as a means of estimating the continental influence on oceanic sedimentation.

One of the basic aims of the onshore activities in the coastal basins of Morocco was to establish a precise lithologic and stratigraphic subdivision of the Cretaceous rock series. This was done in cooperation with researchers from the University of Tübingen (Wiedmann et al., $1978,1982)$, who erected standard sections for the Cretaceous near the Atlantic coast between Agadir and Cap Rhir, and near Essaouira. The Askouti section described in this paper represents the eastern landward facies of the High Atlas Cretaceous deposits. Located about 20 $\mathrm{km}$ inland (Fig. 1) the Lower to mid-Cretaceous sequence of Askouti contrasts with the western margin facies near Agadir. It displays frequent alternation of marine and nonmarine sediments and exhibits characteristics transitional between the open-marine Atlantic province to the west and the basin margin province to

\footnotetext{
${ }^{1}$ Hinz, K., Winterer, E. L., et al., Init. Repts. DSDP, 79: Washington (U.S. Govt. Printing Office).

2 Addresses: (Butt, present address) Al Rahim 50 II B, Model Town, Lahore, Pakistan; (Wurster, Stets) Geologisches Institut der Universităt Bonn, Nussallee 8, D-5300 Bonn 1, Federal Republic of Germany.
}

the east. The eastern province is characterized by a more abrupt alternation from lagoonal to continental and openmarine sediments (Wurster and Stets, 1982, figs. 2, 6).

Detailed study of the Western High Atlas began in 1930 with work by Roch. It was continued by Ambroggi (1963) and Duffaud et al. (1966). Some important geologic aspects of the Mesozoic deposits of the Western High Atlas were also discussed by Ager (1974). Although Ambroggi made a detailed study of stratigraphy and paleontology, little attention was paid to environmental, ecological, and bathymetric aspects of the Cretaceous. Wurster and Stets (1982, fig. 9) established a sedimentation model for the Lower to mid-Cretaceous sequence of the Western High Atlas, using lithological data because the sediments are often barren of foraminifers. In the Askouti area the microfossils are locally rich, and this model is now corroborated by the micropaleontological record provided by A. Butt.

\section{GEOLOGICAL SETTING}

The Askouti section is situated at the southwestern edge of the Western High Atlas mountain range, in the Imouzzer des Ida Ou Tanane area. Toward the south it is bordered by the Plain of Souss, which is filled with Quaternary sediments. The Mesozoic rock series cropping out in the southwestern High Atlas extends from the Triassic to the Cretaceous. In general, younger sediments successively appear toward the coastline, as the mountain chain plunges toward the Atlantic Ocean. This geological situation is modified (Fig. 1) by anticlinal and synclinal structures that are the structural response to a fault pattern which affected the Paleozoic basement. In contrast to the structural interpretation of Rod (1962), this chapter does not distinguish a distinct fault cutting through the Mesozoic-called the "Agadir fault"-in this region. 


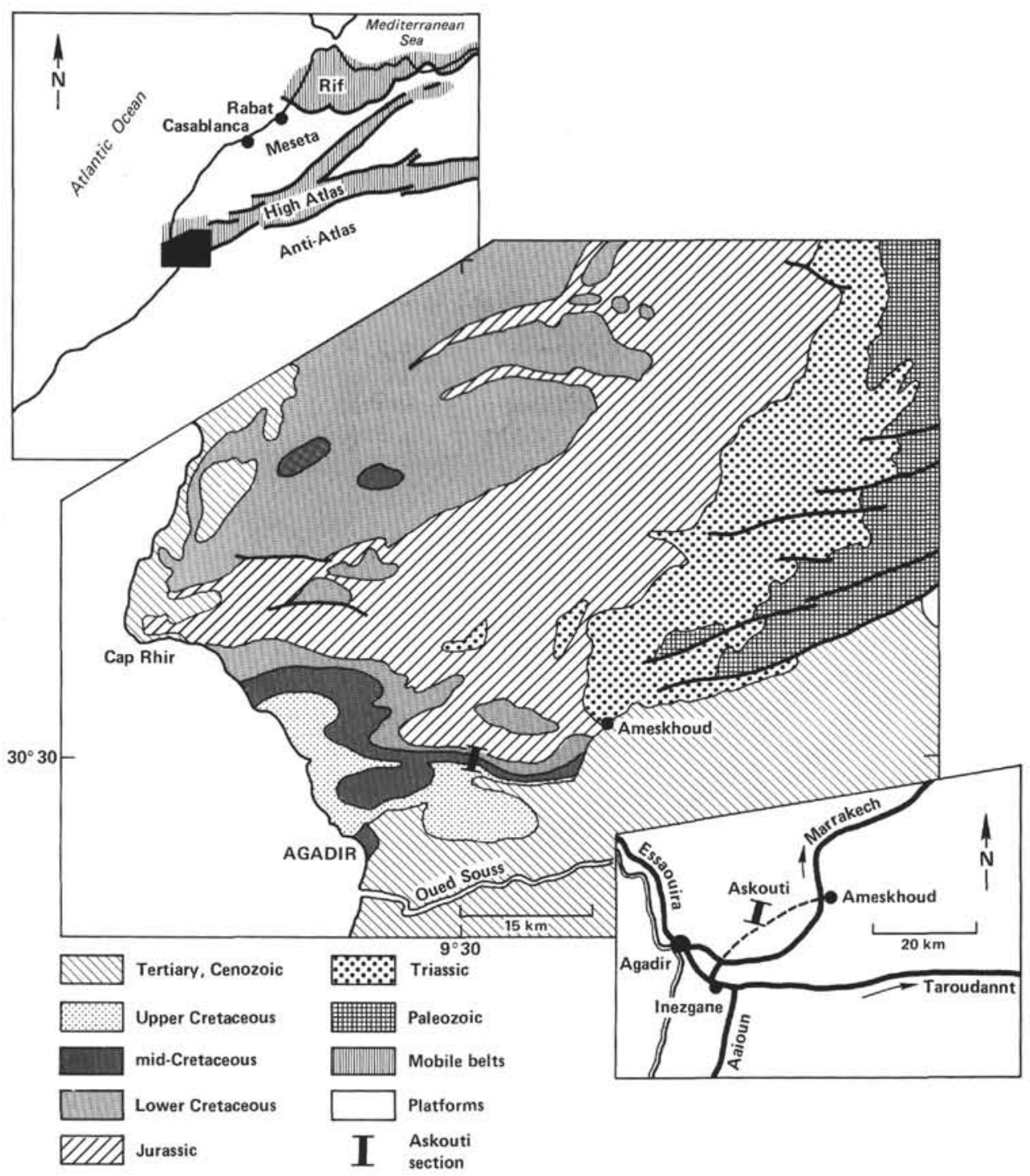

Figure 1. Geology of the southwestern edge of the Moroccan High Atlas and location of the Askouti section.

The Askouti section is located at the southern flank of one of these anticlinal structures, the anticline of Djebel Lgouz. Here, the Cretaceous sequence crops out in the valley south of the small village of Askouti. Bedding dips steeply toward the north at the inverted limb of the anticline. According to the correlation of the Cretaceous rock series with those farther to the west and in the Ameskhoud area to the east, the profile is affected by two minor faults (see Fig. 3, later). Nevertheless, from the stratigraphic point of view, the Askouti section contains the complete Lower to mid-Cretaceous sequence from which the micropaleontological and sedimentological aspects of onshore basin development are deduced.

\section{PALEOGEOGRAPHICAL SETTING}

A well-defined deltoid sedimentary basin, called the Atlas-Gulf (Behrens et al., 1978) is apparent from profiles currently available from the Western High Atlas Cretaceous (Wurster and Stets, 1982). This Gulf stretches landward to the east and is bordered by two stable plat- form areas: the Moroccan Meseta to the north, and the Anti-Atlas to the south. Thin sedimentary units occur at the margins of these structural and paleogeographical highs (Fig. 2). The deltoid/triangular Atlas-Gulf opens toward the Atlantic, and the sedimentary sequence increases in thickness toward the interior and toward the Atlantic along the axis of the basin. Toward the east, the sedimentary sequence decreases gradually in thickness, and red beds are found increasingly in the Atlas-Gulf. Accompanying facies changes are discussed in more detail by Wurster and Stets (1982); the western margin is considered by Wiedmann et al. (1978) and Butt (1982).

The structural position of the Gulf area roughly coincides with the Mesozoic Atlas Rift, which here intersects with the Atlantic continental margin (Stets and Wurster, 1982). According to data compiled for the Gulf area, subsidence during Early and mid-Cretaceous time took place rather continuously, whereas the neighboring stable platform areas remained elevated. In Late Cretaceous time conditions changed. From the Turonian on- 


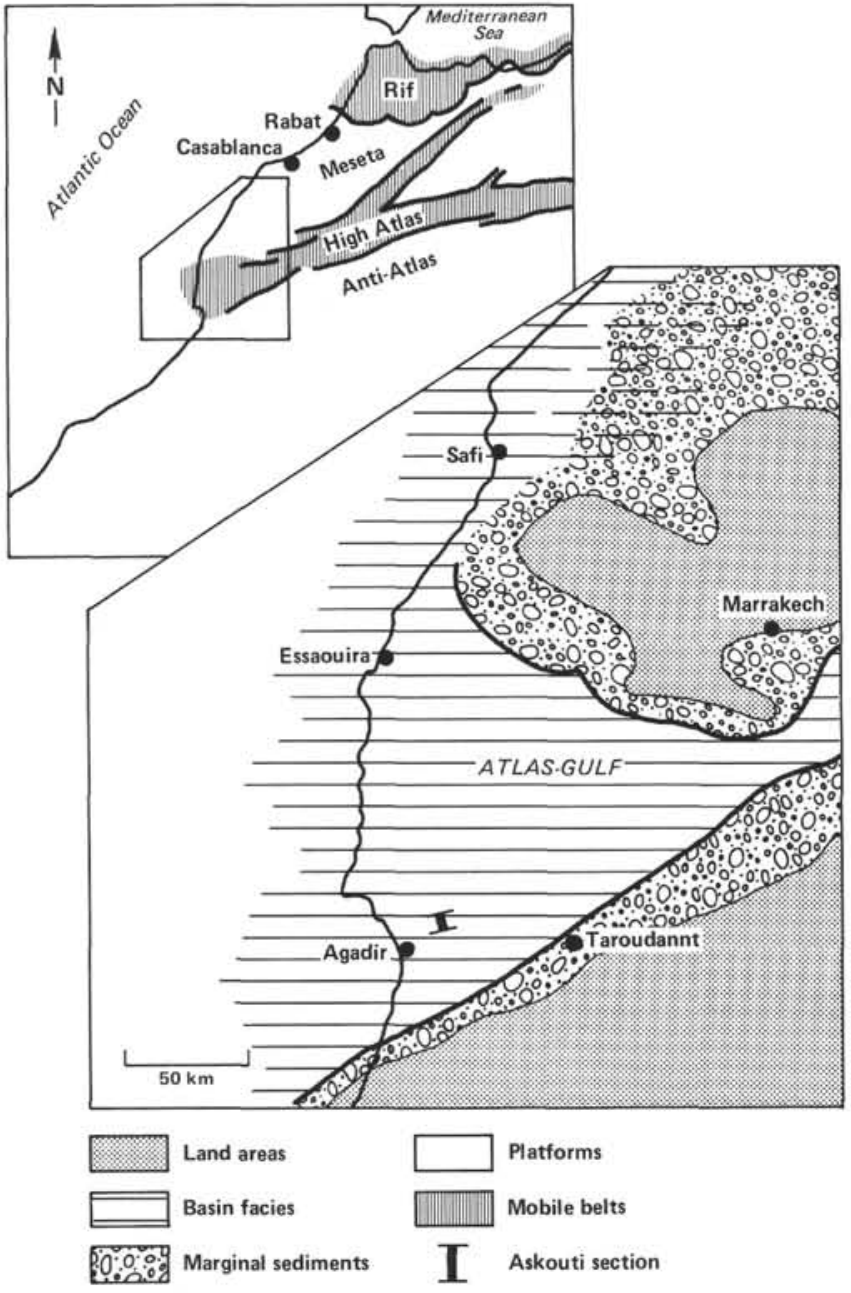

Figure 2. General configuration of the Early to mid-Cretaceous AtlasGulf and adjacent areas of the Moroccan Meseta and the AntiAtlas.

ward, two separate basins developed along the northern and southern flank of the rising High Atlas mobile belt.

\section{ASKOUTI SECTION}

The Askouti section is divided into two parts termed $\mathrm{Aa}$ and A (Fig. 3); both are located along the valley south of Askouti at approximately $30^{\circ} 30.0^{\prime} \mathrm{N}, 9^{\circ} 27.8^{\prime} \mathrm{W}$. Part Aa comprises the Lower Cretaceous, part A the mid-Cretaceous. The sedimentary sequence is subdivided into several rock units as generalized in the stratigraphic column of Figure 3. The section was surveyed in detail by Wurster and Stets at a scale of 1:50. A. Butt conducted the micropaleontological research.

\section{Berriasian to lower Aptian Sequence}

The lowest rock unit (Aa 270-289 m) conformably overlies an Upper Jurassic sequence of alternating wellbedded carbonates and marls. This first Cretaceous unit consists of grey to greenish marls, dolomitic limestones, and arenites. It is followed by a limestone sequence (Aa 289-320 m) with interbedded thin layers of marls, in which the limestones contain oysters with shell diameters up to $120 \mathrm{~mm}$, brachiopods, echinoids, and occa- sional corals. Above the limestones, gray marls grade upward into red marls (Aa 320-360 m). A fault forms the upper contact of the red beds. The next series (Aa $360-400 \mathrm{~m}$ ) starts with intraformational breccias and layered conglomerates with interbedded marls. Grey to greenish marls again follow with interbedded dolomitic limestones. The limestones contain quartz (up to 20\%) and shell debris. At Aa $400 \mathrm{~m}$ the next rock unit again begins with a basal conglomeratic and calcarenitic sequence that exhibits occasional large-scale cross-bedding. Pebbles reach diameters up to $5 \mathrm{~mm}$ and intercalated oyster shells range to $40 \mathrm{~mm}$. Layers rich in shell debris occur. Above this coarse-grained littoral sediment, red and grey marls follow that are rich in brachiopods, especially at Aa $430-435 \mathrm{~m}$ and Aa 441-443 m. The sequence from Aa 443 to Aa 460 m consists of multicolored, red to grey marls, interbedded limestones, and nodular dolomites. Oysters with shell diameters up to 50 $\mathrm{mm}$ occur in the lower portion of the sequence, whereas the upper part is unfossiliferous.

\section{Aptian-Albian Sequence}

At Aa $460 \mathrm{~m}$ the next sequence starts with another basal conglomerate, consisting mostly of quartz pebbles, that represents the main transgressive event of the Early Cretaceous. This conglomerate is overlain by marls and calcarenites followed by a well-bedded sequence of grey marls and interbedded micritic limestones that contain complete shells and shell debris of small oysters, brachiopods, other mollusks, and ammonites up to $492 \mathrm{~m}$. The ammonite faunas indicate the first occurrence of open marine environments within the gulf. According to Wiedmann (pers. comm., 1977) this rock unit belongs to the late Aptian (Gargasian, Clansaysian).

The following rock series, from Aa 492 to A $610 \mathrm{~m}$, consists mainly of green to olive marls with bituminous layers and frequent interbedded yellowish layers of calcarenites and calcareous sandstones, a few up to $10 \mathrm{~cm}$ thick. In the lower part (Aa $500 \mathrm{~m}$ ) are oxidized small ammonites and mollusks, in the upper part small oysters and other mollusks occur. The lower sequence is not complete: a fault truncates the unit. In the uppermost part (A 550-610 m) are well-bedded and nodular limestones and calcarenites that contain mollusk shells and shell debris.

The next unit above (A 610-805 m) consists of grey to green marls with four intercalated arenitic rock sequences (series 1-4, Fig. 3), each 15 to $20 \mathrm{~m}$ thick. These consist of reddish to pink calcareous sandstones, grey and white limestones, and dolomitic limestones. Within the calcareous sandstones cross bedding, ripple cross bedding and lamination are observed. In the basal parts of the dolomitic limestones intraformational breccias are often found. Trace fossils are rare, whereas oysters with maximum shell diameters up to $120 \mathrm{~mm}$ and coquina beds are abundant.

\section{Cenomanian-Turonian Sequence}

The sequence from A 805-1125 m consists mainly of grey marls. Intercalations of limestones and calcarenites show cross stratification, shell layers, and coquina beds. 


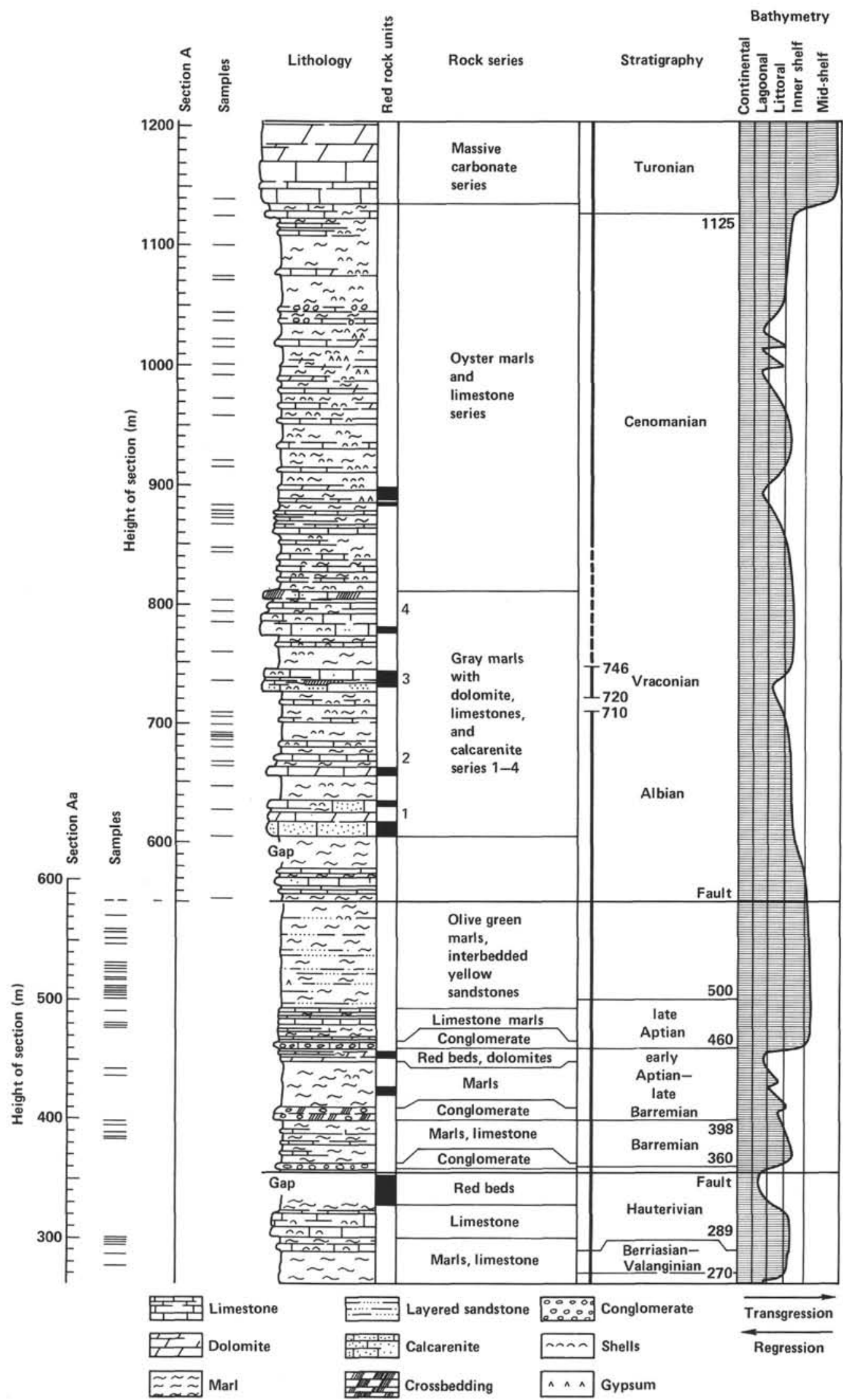

Figure 3. Generalized profile of the Lower and mid-Cretaceous sequence at Askouti, containing standard lithology, rock units, biostratigraphic data, and paleobathymetry. Sample number in text corresponds to the position in sections $\mathrm{Aa}$ and $\mathrm{A}$; stratigraphic boundaries correspond to data in Table 1. 
Rich assemblages of oysters with shell diameters up to $150 \mathrm{~mm}$ suggest nearby oyster reefs. Trace fossils, mollusks, and several fragments of echinoids indicate periods of rich benthic life in some places and at certain times. Dolomite, red marls, and gypsum are also observed. Alternation of these quite different rocks within this sequence suggests that the sediments accumulated under fluctuating shallow-marine to lagoonal conditions.

The uppermost rock unit (A 1125-1200 m) consists of a massive carbonate sequence with limestones and dolomites (Fig. 3). The limestones are often rich in nodules and layers of chert. This unit is followed in the field over large areas and is one of the most important reference horizons of the Cretaceous in the High Atlas. It represents the second main transgressive event in the Cretaceous Atlas-Gulf (Stamm and Thein, 1982).

\section{BIOSTRATIGRAPHY}

Several marlstone samples and thin sections of the carbonate facies were studied to document the following foraminiferal stratigraphy. The stratigraphic scheme (Table 1) is applied following van Hinte (1976). Diagnostic species used in this report are listed in Table 2.

\section{Lower Cretaceous: Berriasian-Aptian (Aa 270-500 m)}

In the lower part of the section, samples Aa 287.0 and Aa 287.7 are dominated by Buccicrenata italica with some rare specimens of Triplasia (Plate 1, Fig. 2). Occurrence of $\boldsymbol{B}$. italica may indicate a Berriasian through

Table 1. Biostratigraphic summary of the Askouti section.

\begin{tabular}{|c|c|}
\hline $\begin{array}{l}\text { Interval }^{\mathrm{a}} \\
(\mathrm{m})\end{array}$ & $\begin{array}{l}\text { Ages with diagnostic } \\
\text { foraminiferal species }\end{array}$ \\
\hline $270-287$ & $\begin{array}{r}\text { Berriasian-Valanginian } \\
\text { Buccicrenata italica }\end{array}$ \\
\hline $289-360$ & $\begin{array}{l}\text { Hauterivian } \\
\text { Dorothia kummi }\end{array}$ \\
\hline $360-398$ & $\begin{array}{l}\text { Barremian } \\
\text { Choffatella decipiens } \\
\text { Dorothia kummi }\end{array}$ \\
\hline $398-460$ & $\begin{array}{l}\text { late Barremian-early Aptian } \\
\text { Barren }\end{array}$ \\
\hline $460-500$ & $\begin{array}{l}\text { late Aptian } \\
\text { Globigerinelloides ferreolensis } \\
\text { Clavihedbergella bizonae } \\
\text { Globigerinelloides blowi }\end{array}$ \\
\hline $500-710 \pm$ & $\begin{array}{l}\text { Albian } \\
\text { Favusella washitensis } \\
\text { Ticinella bejaouaensis } \\
\text { T. primula } \\
\text { Hedbergella amabilis } \\
\text { H. planispira } \\
\text { Globigerinelloides gyroidinaeformis }\end{array}$ \\
\hline $\pm 720-746$ & $\begin{array}{l}\text { Vraconian } \\
\quad \text { Heterohelix moremani }\end{array}$ \\
\hline $746-1125$ & $\begin{array}{l}\text { Cenomanian } \\
\text { Praealveolina } \\
\text { Pseudodomia } \\
\text { Cribratina texana } \\
\text { Gavelinopsis }\end{array}$ \\
\hline $\pm 1130-1200$ & $\begin{array}{l}\text { Turonian } \\
\text { "Zone à grandes Globigérines" }\end{array}$ \\
\hline
\end{tabular}

${ }^{a}$ See Figure 3.
Table 2. Diagnostic species of foraminifers cited in this chapter.

Gavelinella intermedia (Berthelin)
Globigerinelloides blowi (Bolli)
Favusella washitensis (Carsey)
Clavihedbergella bizonae (Chevalier)
Cribratina texana (Conrad)
Valvulineria gracillima (Dam)
Buccicrenata italica Dieni and Massari
Hedbergella infracretacea (Glaessner)
Heterohelix moremani (Morrow)
Globigerinelloides ferreolensis Moullade
Hedbergella sigali Moullade
Globigerinelloides gyroidinaeformis Moullade
Epistomina spinulifera (Reuss)
Pseudonodosaria humilis Roemer
Choffatella decipiens (Schlamberger)
Lamarckina lamplughi (Sherlock)
Tichinella bejaouaensis Sigal
Hedbergella planispira (Tappan)
Hedbergella amabilis (Tappan)
Dorothia kummi Zedler

Valanginian age for the lowermost rock unit (Aa 270289 m, Fig. 3). Ascoli (1976) reported B. italica from the Cretaceous shelf basin of Nova Scotia, North America; thus an isochronic biostratigraphic level between the High Atlas and Nova Scotian basins is indicated. Samples Aa 296.0 and Aa 299.0 contain rare specimens of Dorothia kummi, Ammodiscus, and Lenticulina, abundant echinoid spines, and small mollusks that suggest a probable early Hauterivian-Valanginian age. The red bed facies of Hauterivian age (Aa 330-360 m, Fig. 3) is barren of microfossils.

The lower Barremian marls and interbedded limestone samples in the interval Aa 380 to $398 \mathrm{~m}$ contain variable amounts of ostracodes and of calcareous benthic and agglutinated foraminifers. The assemblage also includes sporadic distribution of small mollusks, echinoid spines, and a few bryozoans. Typical Barremian species include Dorothia kummi and Choffatella decipiens in addition to Trochammina depressa and species of Lenticulina, $\mathrm{Ha}$ plophragmoides, and Ammobaculites. The upper Barremian-lower Aptian facies (Aa $398-460$ m, Fig. 3) is almost barren of microfossils.

The overlying marls and limestones in the Aa 460-500 $\mathrm{m}$ interval contain relatively abundant foraminifers. Planktonic species indicate a late Aptian age (samples Aa 443.5; Aa 475.5; Aa 481.0; Aa 490.7; Aa 497.1). Typical Aptian species include Globigerinelloides ferreolensis, G. blowi, Clavihedbergella bizonae, Hedbergella infracretacea, $H$. planispira, $H$. sigali, and Ticinella bejaouaensis. Some benthic taxa are Vaginulina, Lenticulina, Dentalina, Frondicularia, Nodosaria, Epistomina spinulifera, Gavelinella intermedia, and Lamarckina lamplughi. In addition, the assemblage also shows sporadic occurrence of Dorothia, Textularia, Tritaxia, and Reophax. Sample Aa 481.0 typically contains upper Aptian species, and planktonic: benthic ratios average 20:80 (Plate 1, Fig. 1). In general, the upper Aptian samples contain relatively abundant nodosariids, whereas rotaloid forms and agglutinated foraminifers are rare. 


\section{Mid-Cretaceous: Albian-Turonian} (Aa 500-A 1200 m)

The Aptian-Albian boundary occurs at approximately $500 \mathrm{~m}$, whereas the Albian extends upward to more than $710 \mathrm{~m}$ in the Askouti section (Fig. 3).

The Lower Albian marls contain rare planktonic foraminifers, but benthic foraminifers are frequent and diverse. Typical planktonics are Ticinella bejaouaensis, Favusella washitensis, T. primula, Hedbergella amabilis, and $H$. planispira. Typical benthics are Valvulineria gracillima and Epistomina spinulifera. Nodosariids are abundant with a high frequency of lenticulines, but agglutinated foraminifers such as Textularia, Dorothia, Reophax, and Haplophragmoides are rare; sample Aa 517.5 yields an abundant assemblage of Trochammina depressa.

The middle and upper Albian series (samples Aa 552.2, Aa 557.0, Aa 560.0, A 627.5, A 647.5, A 680.0, A 685.9, A 688.0 , A 689.0, A 692.5, A 699.0, and A 709.5 ) in the interval from 552 to $710 \mathrm{~m}$ are nearly devoid of pelagics, and the upper Albian samples from A 605 to $710 \mathrm{~m}$ are barren of planktonic species. However, some middle Albian species include Globigerinelloides gyroidinaeformis, Hedbergella amabilis, and H. planispira. These foraminifers are epipelagics (they inhabited the upper few meters of the water column) and indicate nearshore conditions. Benthic foraminifers are rare to frequent, and ostracodes show variable abundances; echinoid spines, small mollusks, and fish teeth occur as minor components in the samples. Interestingly, the upper Albian sample yields relatively abundant fresh-or brackish-water algae (charophytes, Plate 2, Fig. 1), and ostracodes. Typical benthic foraminiferal species are Valvulineria gracillima, Pseudonodosaria humilis, extremely small specimens of Dentalina, and relatively common lenticulines.

The uppermost Albian, or so-called Vraconian, includes oyster limestones and interbedded marls (samples A 735.0; A 760.5; A 784.7; A 802.7; A 844.0). The marl samples contain abundant epipelagic heterohelicids such as Heterohelix moremani (samples A 760.5; A 802.7). The assemblage also includes other minor components such as ostracodes, small mollusks, and agglutinated foraminifers such as Haplophragmoides. The interbedded calcareous limestones and calcarenites yield specimens of Dicyclina, miliolids (Quinqueloculina, Cuneolina), and shell debris, including echinoid spines and algal fragments (A 735.5; A 847.7).

The first occurrence of Praealveolina in sample A 846.3 marks the Vraconian/Cenomanian boundary; the Cenomanian is represented in the interval from A 846 to $1125 \mathrm{~m}$ in the Askouti section. The Cenomanian sequence displays an upward continuation of the underlying Vraconian facies. Thin sections of samples A 846.3, A 866.5, A 874.3, and A 1046.0 include imperforate foraminifers such as Praealveolina, Pseudodomia, Quinqueloculina, and Dicyclina, algal fragments, and shell debris. These microfossils are embedded in sparry oolitic and intraclastic micritic matrix (Plate 3, Figs. 1-3).

The marl samples A 877.2, A 879.0, A 921.3, and A 972.5 represent an early Cenomanian age. They contain rare to common benthic microfossils, whereas planktonic species are absent. The lower Cenomanian assemblage includes Quinqueloculina, Cribratina texana, Cuneolina, Daxia, and Gavelinopsis. In addition to this benthic fauna, the assemblage yields abundant ostracodes in some samples; small mollusks, bryozoans, and echinoid spines are present as minor components. Sample A 993.5 in the upper part of the early Cenomanian is barren of microfossils; the washed residue contains only gypsum fragments. Sample A 1001.5 consists mainly of agglutinated foraminifers including Haplophragmoides, Ammobaculites, and Reophax (Plate 2, Fig. 2). The upper Cenomanian samples (A 1014.2, A 1037.1, A 1046.5, A 1071.5, A 1073.5, A 1100.0, and A 1125.0) display variable amounts of ostracodes and calcareous benthic foraminifers (Plate 2, Fig. 3). The benthic forms include Ammobaculites, Cribratina texana, Haplophragmoides, and Cuneolina. The rotaliid forms such as Gavelinopsis are frequently distributed in the upper Cenomanian samples. Other miscellaneous microfossils such as echinoid spines, bryozoans, and small mollusks were found.

The lithologic change at A $1125 \mathrm{~m}$ (Fig. 3) coincides with the biostratigraphic boundary, marking an important stratigraphic horizon at $1125-1200 \mathrm{~m}$ in the Askouti section that can be correlated in the entire High Atlas region. Sample 1139.0 exhibits a foraminiferal biomicrite microfacies (Plate 3, Fig. 4) containing small-sized and abundant hedbergellids. The hedbergellids in the fine, muddy matrix correspond stratigraphically to the Hedbergella lehmanni Zone-“Zone à grandes Globigérines" of the lower Turonian proposed by van Hinte (1976). This zone is also identified in the western facies of the Atlas-Gulf (Wiedmann et al., 1978; Butt, 1982).

\section{PALEOECOLOGY, PALEOENVIRONMENT, AND PALEOBATHYMETRY}

After the deposition of the Upper Jurassic shallowwater carbonate platform facies (Adams, 1979), the Atlas-Gulf evolved into a near-shore shelf environment during the Berriasian through Valanginian. The interbedded oyster shell beds and marly limestones containing abundant lituolids such as Buccicrenata italica (Plate 1, Fig. 2) and rare Triplasia suggest an intertidal water mass within the littoral zone, with water depths of a few meters. Rare specimens of textulariids such as Dorothia, nodosariids such as Lenticulina, and Ammodiscus, including rare bryozoans near the Valanginian-Hauterivian boundary, imply a progressive deepening of the basin during the Cretaceous transgression (Fig. 3). The Hauterivian red bed facies, however, suggest a regression and lowering of the sea level.

The Lower Barremian facies apparently represent lagoonal to inner-shelf environments with oscillating brackish conditions following the Hauterivian shallowing event. This interpretation is based on the presence of relatively abundant ostracodes, nodosariids such as Lenticulina, and variable amounts of foraminifers such as Haplophragmoides, Ammobaculites, and Trochammina depressa, as well as other miscellaneous microfossils, such as echinoid spines, small mollusks, and rare bryozoans.

The upper Barremian to lower Aptian deposits (Fig. 3) reveal nonmarine fluviatile to deltaic activity. These 
sediments document a retreat of the sea level, revealing another basinwide regression of marine conditions.

The upper Aptian marls contain abundant nodosariids such as Lenticulina, Nodosaria, Frondicularia, and Dentalina, rotaliid forms such as Gavelinella and Epistomina, and rare to common small planktonic foraminifers. Sample Aa 481.0 consists of a relatively diverse foraminiferal assemblage with a planktonic: benthic ratio of 20:80 that suggests an inner-shelf environment with open sea conditions. The upper Aptian flooding, however, marks a basinwide transgression revealing both a submergence and elimination of the early Aptian deltaic environment in the inner Atlas-Gulf basin.

The late Aptian deep-water shelf environment continued during the early Albian period. Although the lower Albian facies reveal a marked decrease of the planktonic species, the benthic foraminifers are more diverse; they include upper Aptian long ranging and diverse nodosariids and rotaliid forms such as Valvulineria gracillima. The lower Albian bituminous marls also contain some agglutinated foraminifers such as Reophax, Saccamina, Trochammina, Haplophragmoides, Dorothia, and Textularia. Such facies may signal calcite depletion related to reducing conditions in a relatively deep shelf-basin environment.

The deep-water shelf environment continued, through the middle Albian, but during the late Albian the abundance of the microfossils was greatly reduced; the planktonic foraminifers are absent, and benthic forms are very rare. In contrast, some upper Albian samples consist mainly of abundant ostracodes and charophytes, whereas others include $\mathrm{m}$ : scellaneous microfossils such as echinoid spines and sma'l mollusks. The upper Albian microfossils suggest a shi llowing shelf basin, and the charophyte assemblage indicates brackish to freshwater conditions (Plate 2, Fig. 1).

The uppermost Albian or Vraconian carbonate facies with interbedded marls contains abundant heterohelicids and rare ostracodes, small mollusks, and a few agglutinated foraminifers. These microfossils suggest deepening of the basin following the upper Albian shallowing. The interbedded calcarenites that contain algal fragments and the associated miliolids indicate near-shore deposition.

The Vraconian carbonate depositional environment continued during the Cenomanian period. Imperforate foraminifers such as Praealveolina, Pseudodomia, Quinqueloculina, and Cuneolina, in association with algal fragments, echinoid, and shell debris (Plate 3, Figs. 1-3) embedded in micritic and oolitic matrix, indicate oscillating low- and high-energy environments. The praealveonid microfacies shown in Plate 3 (Figs. 1-3), comprising Praealveolina, Pseudodomia, and Cuneolina, was also documented from the mid-Cretaceous shallow-water deposits in the Tethyan region (Hamaoui, 1979). The algae and larger foraminifers such as Praealveolina and Cuneolina favored warm, sunlit conditions of the littoral zone. Accordingly, interbedded gypsum and red-bed facies suggest intense, warm, hypersaline to oxidizing conditions. Sample A 1001.5, comprising agglutinated foraminifers such as Rheophax, Haplophragmoides, and Ammobaculites, indicates fluctuating hyposaline or salt marsh conditions. Similar depositional environments for the Upper Cretaceous marginal sediments of the Horseshoe region of southern Alberta were proposed on the basis of agglutinated associations by Wall (1976).

The intermittent evaporitic and brackish environment of the late Cenomanian implies a retreat of the sea level. Interbedded marls containing rotaliid forms such as $G a$ velinopsis and agglutinated forms such as Cribratina texana and Cuneolina, with variable ratios of ostracodes to benthic foraminifers and a total lack of pelagic foraminifers, suggest oscillating inner-shelf to lagoonal depositional environments during the Cenomanian (Fig. 3).

During the Turonian, a major facies change occurred. Lithologic data document the cessation of the shallowmarine Cenomanian environments. Abundant hedbergellids (Plate 3, Fig. 4) were apparently deposited in midshelf environments with open sea conditions. The inner Atlas-Gulf basin reveals a greater water depth that coincides with a large-scale submergence and a transgression of the entire Atlas region during the early Turonian. This increase in water depth also corresponds to the deepening of the western margin of the Atlas coastal basin, suggesting a synchronous transgressive event.

\section{PALEOCEANOGRAPHIC REVIEW}

In summary, microfossils from the Lower to mid-Cretaceous sediments of the Askouti section document the development of lagoonal to mid-shelf environments. Combined with lithological data, microfossil data from the section record frequent changes of depositional environments. According to all the data now available, the proposed sedimentation model is based on the assumptions of continuous subsidence in the Gulf, lack of major climatic changes in this region, and a somewhat elevated position of the bordering highs. The model is substantiated by the character of the marginal facies and of the sediments in the interior of the Gulf. Terrigeneous influx from the continent may have continued during the Early to mid-Cretaceous under these conditions.

Figure 4 shows the sedimentation model which was proposed by Wurster and Stets (1982) for the inner part of the Atlas-Gulf using sedimentological data only. Episodic rises of the sea level, shown on the left, correspond with the position of the littoral zone, on the right. Sedimentological and paleoenvironmental data show that subsidence in the Atlas-Gulf was nearly offset by sedimentation during the Cretaceous. According to our model, minor variations or oscillations of the sea level caused major transgressions or regressions that had a strong influence on benthic and planktonic life and controlled the terrigeneous influx from the adjacent continent. High-standing sea levels restricted the clastics from the continent to the inner part of the basin, whereas the lowering of sea level allowed the clastic material to reach the Atlantic coastal margin.

In the sedimentation model the Askouti section is situated to the west, far away from the strong influence of continental conditions (Fig. 4). The micropaleontological data support this model. The low frequency of planktonic foraminifers prohibited us from using planktonic: benthic ratios as a reliable paleobathymetric parameter. 


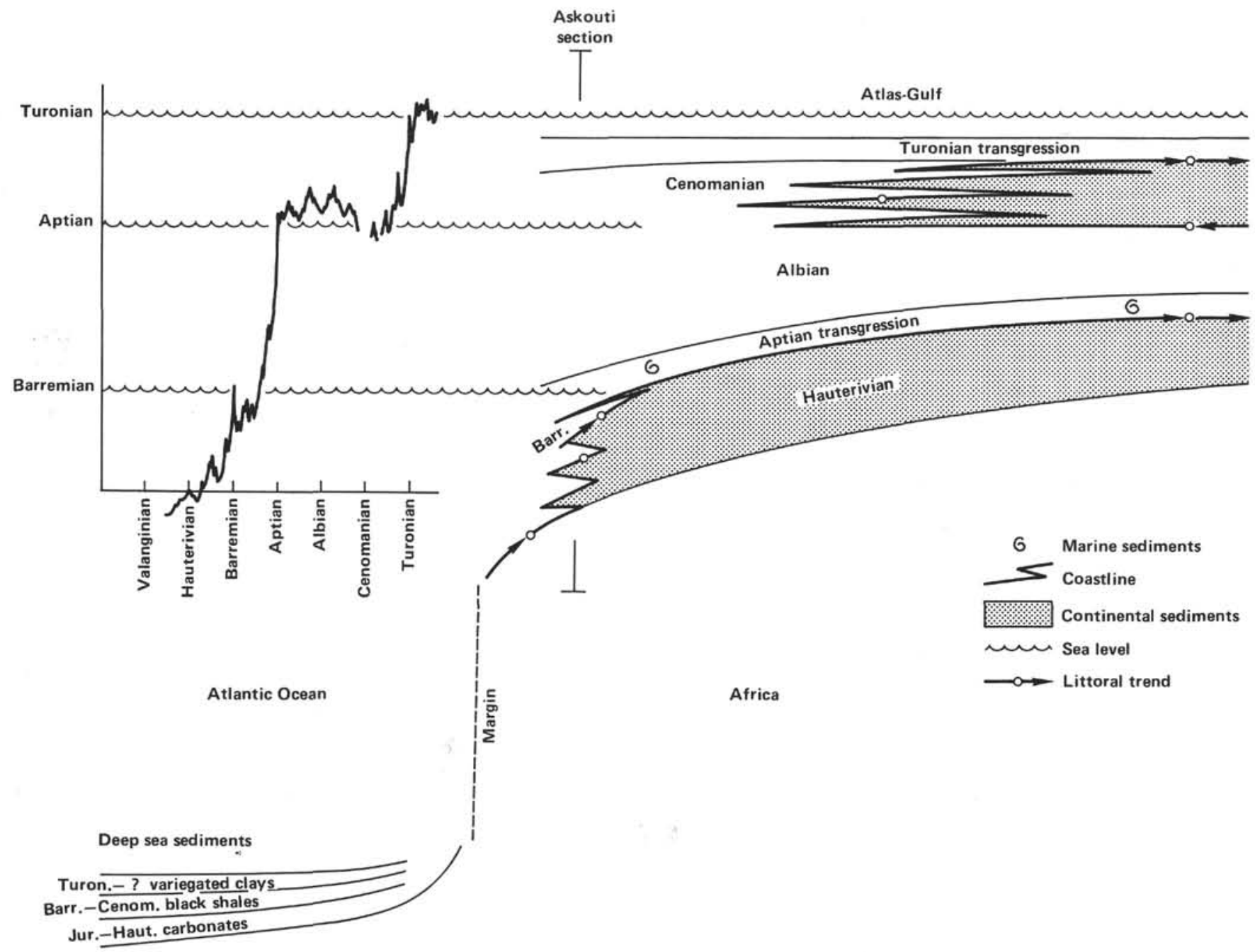

Figure 4. Sedimentation model of the Atlas-Gulf: interpretative sketch elucidating the migration of the littoral zone and the facies distribution, caused by several stages of a rising sea level; based on Wurster and Stets (1982).

Nevertheless, small-sized planktonics reveal epipelagic zone activity from a near-shore water mass. The benthic foraminifers also lived under stressed biotope conditions and were influenced by sediment influx derived from a lowering of sea level. The syndepositional subsidence was nearly continuous, but markedly lower in comparison to the western margin of the Atlas-Gulf (Wiedmann et al., 1978). In response to sea level changes, the basin experienced episodic marine and continental conditions during the Early to mid-Cretaceous period in the Askouti area.

The upper Barremian-lower Aptian deltaic and continental facies and the bituminous olive green marls of early Albian age are equivalents of the deep-sea black shale in the Atlantic Ocean (Fig. 4). The environments of the organic-matter-rich Early Cretaceous facies are discussed by Schlanger and Jenkins (1976) for the other coastal basins around the Atlantic. These authors argued that such facies may indicate oceanwide anoxic events during the Early to mid-Cretaceous because of the restricted circulation and a maximum expansion of the oxygen-minimum zone (Arthur, 1979; Einsele and Wiedmann, 1982; Butt, 1982; Ryan and Cita, 1977).
Following the frequent Cenomanian oscillations in sea level, the inner Atlas-Gulf was submerged under a deeper water mass during the early Turonian. According to Arthur (1979) and Roth and Bowdler (1981), deep-water connections within the Atlantic improved at the end of the mid-Cretaceous, resulting in better ventilation and in the replacement of black shales by a multicolored clay and chalk facies (Fig. 4). Structural opening of the North and South Atlantic may have produced this major paleoceanographic change (Butt, 1982), which in turn controlled the contemporaneous flooding of the coastal basin by the rise in sea level (Sliter, 1977; Wiedmann et al., 1978, 1982; Lancelot and Winterer, 1980; Wurster and Stets, 1982).

Among the variables thought to be responsible for changes of lithofacies, paleoenvironments, paleoecology, and paleobathymetry in the Askouti section and elsewhere in the Gulf area, changes in sea level may have been the most important factor.

\section{CONCLUSIONS}

Detailed studies of a Lower to mid-Cretaceous sequence near Askouti at the southwestern flank of the High At- 
las mountain range corroborate data from Atlantic Ocean sediments and from sediments in the interior of the Atlas coastal basin of Morocco.

1. The Askouti section is subdivided into several rock units which reflect frequent changes in sedimentary depositional environments, ranging from continental red beds to open marine carbonates. Different transgressive events are documented by conglomerates in the Barremian and late Aptian and by marine carbonates in the Berriasian-Valanginian and in the Turonian; regressions are expressed by deltaic to fluviatile red beds in the Hauterivian and in the late Barremian to early Aptian, and by lagoonal deposits containing gypsum in the Cenomanian.

2. The micropaleontological record supported by planktonic and benthic foraminifers allows an approximate biostratigraphic classification of the rock units. Stratigraphic boundaries are less precise in unfossiliferous parts of the section or those barren of conclusive foraminifers such as those of the Vraconian and Cenomanian sequences.

3. Foraminifers, ostracodes, charophytes, and other miscellaneous microfossils and relics display shallow-marine to logoonal and brackish depositional environments, with relatively frequent oscillation of water depths during the Early to mid-Cretaceous. Marine sediments range from the littoral zone to mid-shelf conditions. The transgressions and regressions suggested by the lithological data in the Askouti section are thus sustained by the micropaleontological record. Increasingly frequent changes of living and depositional conditions during the latest Albian and the Cenomanian are documented.

4. A sedimentation model based on the data now available suggests that eustatic sea level changes versus subsidence are considered the main factors that controlled depositional conditions, paleoecology, and paleoenvironment. Within this model, it is suggested that major rises of the sea level occurred in the late Aptian and early Turonian, minor ones in the Berriasian to Valanginian, early Barremian, and Cenomanian.

\section{ACKNOWLEDGMENTS}

The authors are indebted to Drs. Hilali, Bensaid, and Dahmani (Ministère de l'Energie et des Mines, Division de la Géologie), Rabat, Morocco, who facilitated the field work in the High Atlas in every respect. For critically reviewing the draft of the manuscript, we thank Drs. H. P. Lutherbacher, Tübingen, K. Hinz, Bundesanstalt für Geowissenschaften und Rohstoffe, Hannover, and Don Eicher, Colorado. Thanks are also due to Dr. D. Herm, Munich, for providing useful references. William v. Sliter, U.S. Geological Survey, Menlo Park, California, kindly commented upon the manuscript, and improved the English style. Field work done in 1975 to 1982 was largely supported by the German Science Foundation, Bonn (DFG, grants Wu 32/15-20).

\section{REFERENCES}

Adams, A. E., 1979. Sedimentary environment and palaeogeography of the Western High Atlas, Morocco, during the Middle and Late Jurassic. Palaeogeogr., Palaeoclimatol., Palaeoecol., 28:185-196.

Ager, D. V., 1974. The Western High Atlas of Morocco and their significance in the history of the North Atlantic. Proc. Geol. Ass., 85:23-41.

Ambroggi, R., 1963. Etude Géologique du Versant Méridional du Haut Atlas Occidental et de la Plaine du Souss. Notes Mem. Serv. Geol. Maroc, 157.

Arthur, M. A., 1979. North Atlantic Cretaceous shales: The record at Site 398 , and a brief comparison with other occurrences. In Si- buet, J.-C., Ryan, W. B. F., et al., Init. Repts. DSDP, 47, Pt. 2: Washington (U.S. Govt. Printing Office), 719-752.

Ascoli, P., 1976. Foraminiferal and ostracod biostratigraphy of the Mesozoic-Cenozoic, Scotian Shelf, Atlantic Canada. Marit. Sediments, Spec. Publ. 1 (B, Paleoecol. Biostratigr.): 653-741.

Behrens, M., Krumsiek, K., Meyer, D. E., Schäfer, A., Siehl, A., Stets, J., Thein, J., Wurster, P., 1978. Sedimentationsabläufe im Atlas-Golf (Kreide-Küstenbecken Marokko). Geol. Rundsch., 67:424-453.

Behrens, M., and Siehl, A., 1982. Sedimentation in the Atlas Gulf I: Lower Cretaceus clastics. In von Rad, U., Hinz, K., Sarnthein, M., and Seibold, E. (Eds.), Geology of the Northwest African Continental Margin: Berlin (Springer-Verlag), pp. 427-438.

Butt, A., 1982. Micropaleontological bathymetry of the Cretaceous of western Morocco. Palaeogeogr., Palaeoclimatol., Palaeoecol., 37: 235-275.

Duffaud, M. F., Brun, L., and Plauchut, B., 1966. Le bassin du Sudouest Marocain. In Reyre, D. (Ed.), Bassins sédimentaires du litoral Africain. Assoc. Serv. Geol. Afr., 1:5-12.

Einsele, G., and Wiedmann, J., 1982. Turonian black shales in the Moroccan coastal basin: First upwelling in the Atlantic Ocean ? In von Rad, U., Hinz, K., Sarnthein, M., Seibold, E. (Eds), Geology of the Northwest African Continental Margin: Berlin (Springer-Verlag), pp. 396-414.

Hamaoui, M., 1979. Contribution à l'étude du Cénomano-Turonien d'Israél; comparaisons micropaléontologiques avec quelques régions Mésogéennes [Thèse de Doctorat]. Université Pierre et Marie $\mathrm{Cu}$ rie, Paris.

Lancelot, Y., and Winterer, E. L., 1980. Evolution of the Moroccan oceanic basin and adjacent continental margin - a synthesis. In Lancelot, Y., Winterer, E. L., et al., Init. Repts. DSDP, 50: Washington (U.S. Govt. Printing Office), 801-821.

Roch, E., 1930. Etudes Géologiques dans la Région Méridional du Maroc occidental. Notes Mem. Serv. Geol. Maroc, 9.

Rod, E., 1962. Fault pattern, northwest corner of the Sahara Shield. Am. Assoc. Pet. Geol. Bull., 46:529-552.

Roth, P. H., and Bowdler, J. L., 1981. Middle Cretaceous calcareous nannoplankton biogeography and oceanography of the Atlantic Ocean. In Warme, J. E., Douglas, R. G., and Winterer, E. L. (Eds.), The Deep Sea Drilling Project: A Decade of Progress. Soc. Econ. Paleontol. Mineral, Spec. Publ., 32:517-546.

Ryan, W. B. F., and Cita, M. B., 1977. Ignorance concerning episodes of oceanwide stagnation. Mar. Geol., 21:197-215.

Schlanger, S. O., and Jenkyns, H. C., 1976. Cretaceous oceanic anoxic events: Causes and consequences. Geol. Mijnbouw, 55:179-184.

Sliter, W. V., 1977. Cretaceous foraminifers from the Southwestern Atlantic Ocean, Leg 36, Deep Sea Drilling Project. In Barker, P. F., Dalziel, I. W. D., et al., Init. Repts. DSDP, 36:519-537.

Stamm, R., and Thein, J., 1982. Sedimentation in the Atlas Gulf III: Turonian carbonates. In von Rad, U., Hinz, K., Sarnthein, M., and Seibold, E. (Eds.), Geology of the Northwest African Continental Margin: Berlin (Springer-Verlag), pp. 459-474.

Stets, J., and Wurster, P., 1982. Atlas and Atlantic-structural relations. In von Rad, U., Hinz, K., Sarnthein, M., and Seibold, E. (Eds.), Geology of the Northwest African Continental Margin: Berlin (Springer-Verlag), pp. 69-85.

van Hinte, J. E., 1976. A Cretaceous time scale. Am. Assoc. Pet. Geol. Bull., 60:269-287.

Wall, J. H., 1976. Marginal marine foraminifera from the Late Cretaceous Bearpaw-Horseshoe Canyon Transition, Southern Alberta, Canada. J. Foram. Res., 6:193-201.

Wiedmann, J., Butt, A., and Einsele, G., 1978. Vergleich von marokkanischen Kreideküstenaufschlüssen und Tiefseebohrungen (DSDP): Stratigraphie, Paläoenvironment und Subsidenz an einem passiven Kontinentalrand. Geol. Rundsch., 67:454-508.

1982. Cretaceous stratigraphy, environment, and subsidence history at the Moroccan continental margin. In von Rad, U., Hinz, K., Sarnthein, M., and Seibold, E., Eds., Geology of the Northwest African Continental Margin: Berlin (Springer-Verlag), pp. 366-395.

Wurster, P., and Stets, J., 1982. Sedimentation in the Atlas Gulf II: Mid-Cretaceous events. In von Rad, U., Hinz, K., Sarnthein, M., and Seibold, E. (Eds.), Geology of the Northwest African Continental Margin: Berlin (Springer-Verlag), pp. 439-458.

Date of Initial Receipt: May 24, 1983

Date of Acceptance: October 25, 1983 
A. BUTT, J. STETS, P. WURSTER
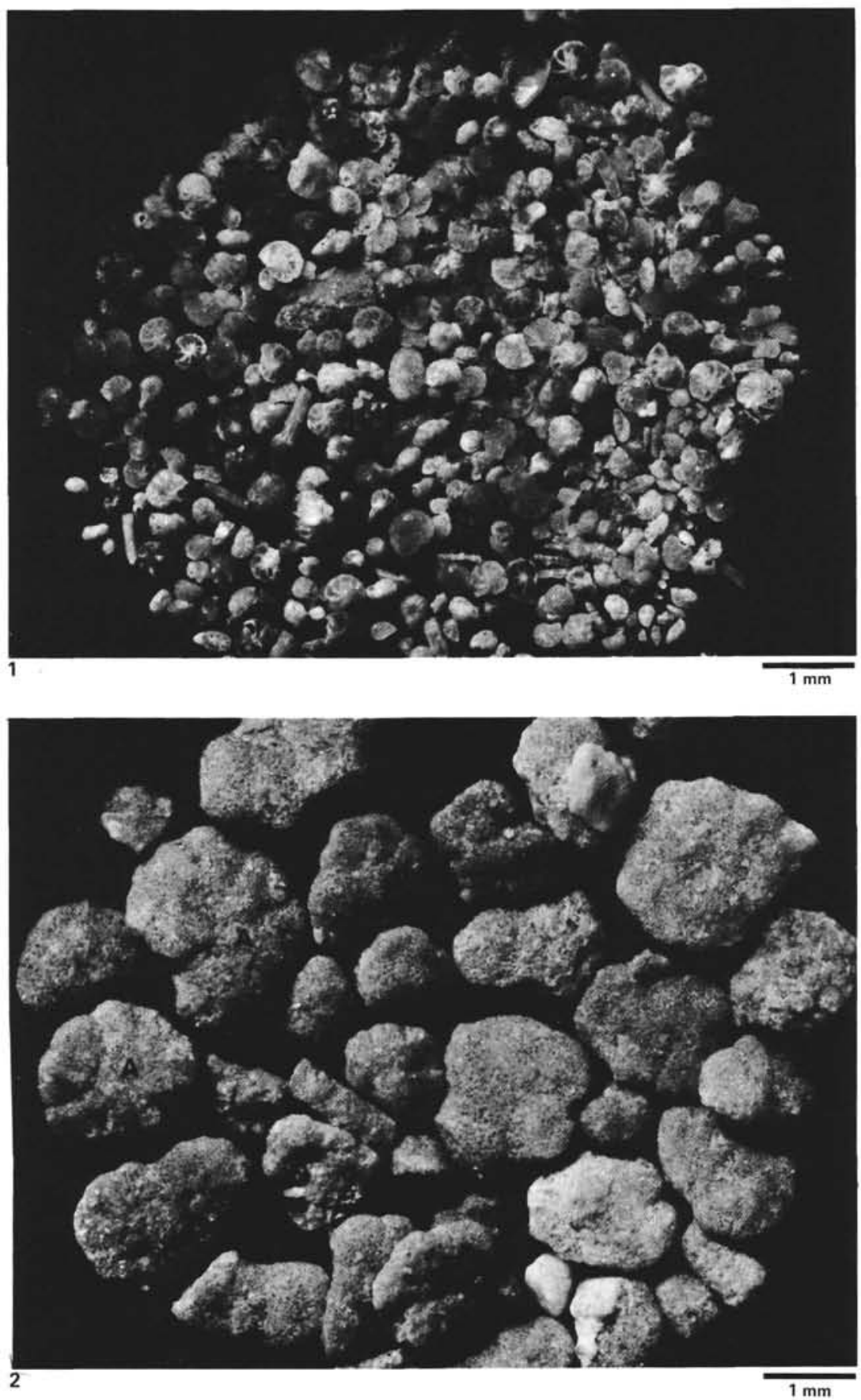

Plate 1. Lower Cretaceous microfossils in the High Atlas coastal basin. 1. Upper Aptian nodosariids; note abundant lenticulines and rare echinoid spines. Paleobathymetric zone, inner shelf; Askouti section, sample Aa 481.0. 2. Berriasian-Valanginian assemblage of Buccicrenata itali$c a$ Dieni and Massari (A). Paleobathymetric zone, littoral; Askouti section, sample Aa 287.0. 

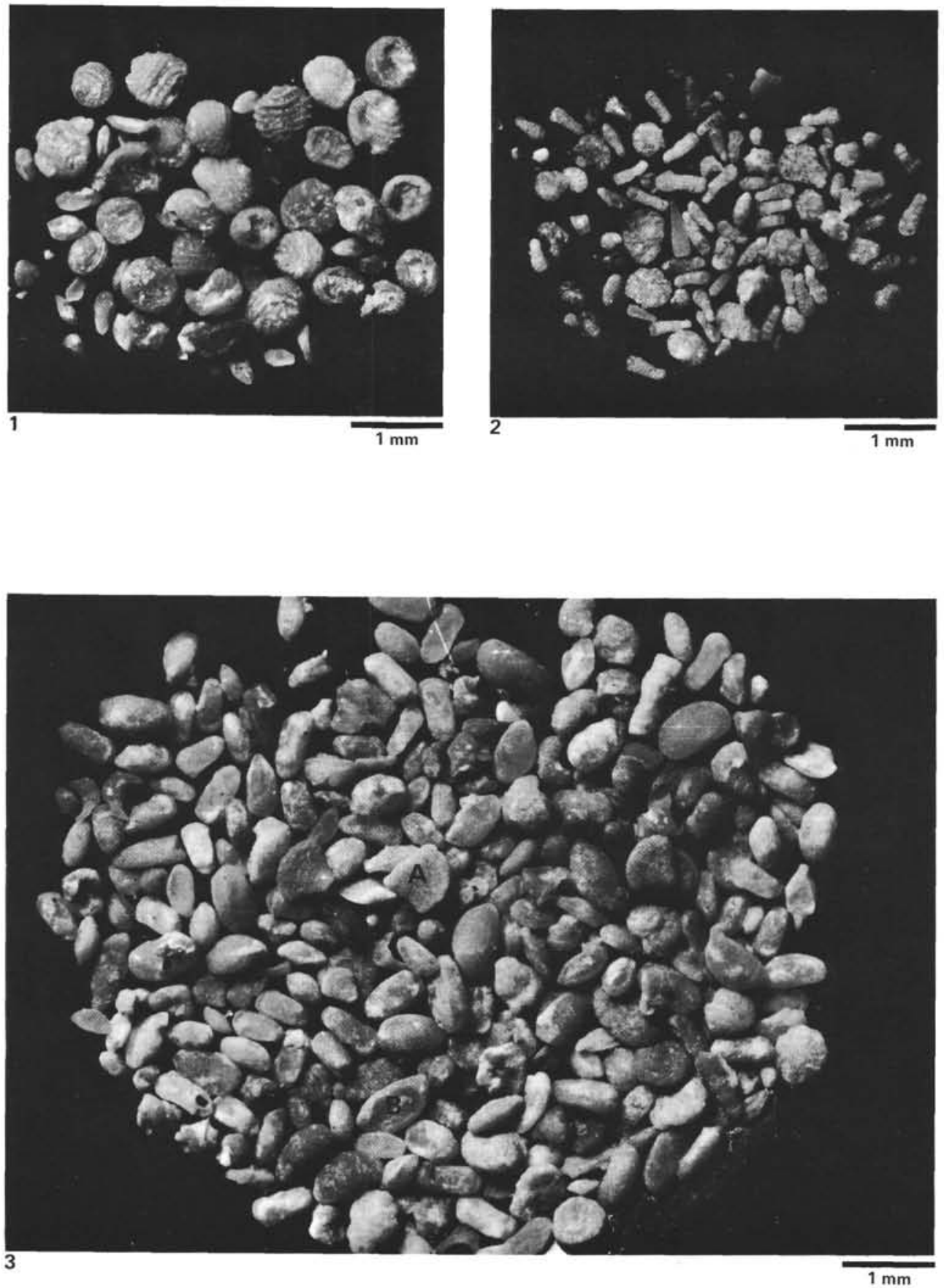

Plate 2. Mid-Cretaceous microfossils in the High Atlas coastal basin. 1. Upper Albian charophyte assemblage. Paleobathymetric zone, lagoonal with brackish or freshwater conditions; Askouti section, Sample Aa 709.5. 2. Upper Cenomanian agglutinated foraminiferal assemblage, showing specimens of Reophax, Ammobaculites, and Haplophragmoides. Paleobathymetric zone, lagoonal with brackish or salt marsh conditions; Askouti section, Sample A 1001.5. 3. Upper Cenomanian microfossil assemblage; note abundant ostracodes and rare foraminifers such as Cuneolina (A) and Quinqueloculina (B). Paleobathymetric zone, lagoonal-inner shelf; Askouti section, Sample Aa 972.5. 

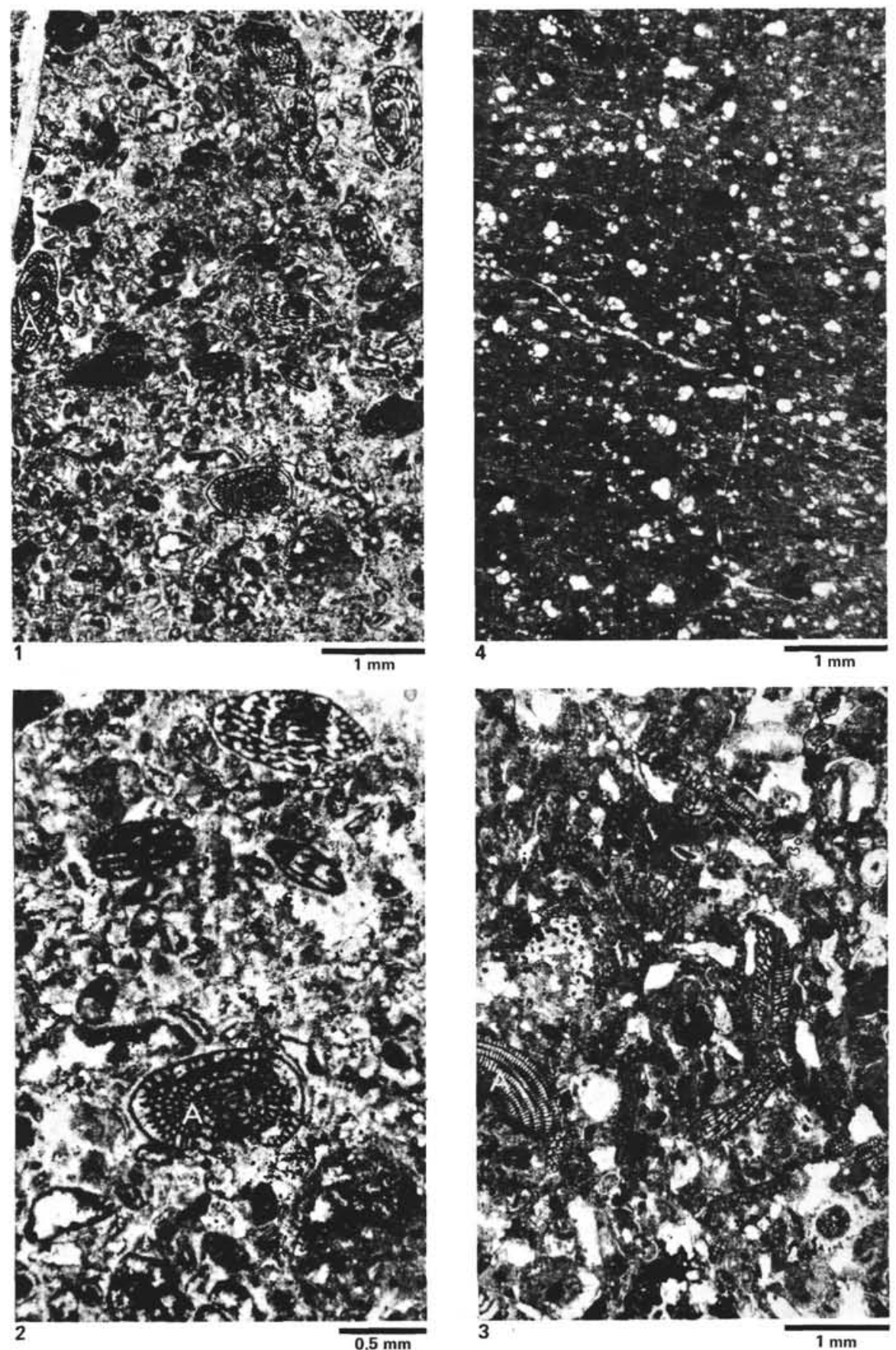

Plate 3. Photomicrographs of mid-Cretaceous microfacies in the High Atlas coastal basin. 1. Cenomanian praealveolinid biomicrite (A). Paleobathymetric zone, near shore-inner shelf; Askouti section. 2. Enlargement of 1. Specimen of Pseudedomia (A)? 3. Cenomanian cuneolinid intraclastic biomicrite. Paleobathymetric zone, near shore-inner shelf; (Cuneoliona (A). Askouti section. 4. Early Turonian globigerinid biomicrite. Paleobathymetric zone, mid-shelf (Hedbergella lehmanni, "Zone à grandes Globigérines"); Askouti section. 